\title{
Genetic Differentiation and Phylogenetic Relationships of an Avian Family, Alcidae (Auks)
}

\author{
Masayoshi Watada*,1, Ryozo Kakizawa*, Nagahisa Kuroda* \\ and Seiitiro Utida*
}

\begin{abstract}
Electrophoresis was used in the analysis of 24 protein loci to clarify the genetic differentiation and phylogenetic relationships among 12 species of 10 alcid genera. The intraspecific genetic variation, expressed as the average heterozygosity, was 0.019 , a little lower than the avian average. The genetic distances between the Alcidae, however, were somewhat higher than the avian average: 0.151 for species and 0.442 for genera. This gives genetic support to the current classification of the Alcidae. By comparative analysis of genetic differentiation among alcid species, this family can be divided into two main groups, Alcinae and Fraterculinae. The results of this study of genetic relationships generally support current classification based on morpho-anatomical and ecological studies. However, two points still remain for further analysis: one is genetic similarity between Uria lomvia and Cepphus carbo, and the other is genetic affinity between Aethia cristatella and Cyclorrhynchus psittacula.
\end{abstract}

\section{Introduction}

A small group belonging to the Charadriiformes, the auks (Alcidae) are small- to medium-sized diving sea birds, which are predominantly arctic in breeding distribution and spend the winter season in coastal or offshore areas. Most genera of Alcidae are recorded and some breed in the ocean area around Japan. The 23 species of the Alcidae are split into 13 genera (Morony et al. 1975). There have been several taxonomic studies from the morphological, ecological and electrophoretic viewpoints (Kuroda 1954, 1955, Kozlova 1957, Sibley \& Ahlquist 1972). Morpho-ecologically, many genera have been recognized within the relatively small family Alcidae, but their genetic differentiation and relationships have not been analyzed.

Recently, electrophoretic techniques have been applied in ornithology and, as genetic data on birds have accumulated, comparative studies of protein polymorphism among avian groups have become available. For example, Avise et al. (1982) reported that vireos, a passerine group, showed a larger degree of genetic differentiation than did other bird groups. The data on protein variations have made it possible to analyze genetic relationships among avian species quantitatively.

In the present paper, the affinities among alcid species are analyzed based on electrophoretic variation. Kakizawa et al. (1982) suggested that this family should be divided into two groups, based on their study of mitochondrial malate dehydrogenase (MDH)

Received 20 May 1987

* Yamashina Institute for Ornithology, Konoyama, Abiko, Chiba 270-11 Japan

1 Present address: Cellular and Genetic Toxicology Branch, National Institute of Environmental Health Sciences, P.O. Box 12233, Research Triangle Park, North Carolina 27709, USA 
variation. In the present study, the proteins encoded by 24 loci were examined to provide a more detailed analysis of the relationships between the taxa in this family.

\section{Materials and Methods}

Specimens of the Alcidae were collected primarily from the Hokkaido coast in 1982: some had drowned in fish nets in the northwest Pacific. They were preserved at $-30^{\circ} \mathrm{C}$ until being sent to our laboratory. They included: 1) Brunnich's Guillemot (Uria lomvia), 2) Common Guillemot (Uria aalge), 3) Spectacled Guillemot (Cepphus carbo), 4) Marbled Murrelet (Brachyramphus marmoratus), 5) Ancient Auk (Synthliboramphus antiquus), 6) Cassin's Auklet (Ptychoramphus aleuticus), 7) Parakeet Auklet (Cyclorrhynchus psittacula), 8) Crested Auklet (Aethia cristatella), 9) Least Auklet (Aethia pusilla), 10) Horn-billed Puffin (Cerorhinca monocerata), 11) Horned Puffin (Fratercula corniculata), and 12) Tufted Puffin (Lunda cirrhata). Each bird was defrosted to remove samples of liver and muscle, which were minced for experimental use and preserved at $-80^{\circ} \mathrm{C}$ until electrophoresis. The extracts from liver and muscle were subjected to starch gel electrophoresis to determine the allelic composition at each protein locus. Combinations of tissues and buffer systems for detection of the enzymes are shown in Table 1. The staining methods for enzymes were essentially the same as those described by Shaw \& Prasad (1970), Selander et al. (1970) and Bell et al. (1982). The nomenclature of the alleles and the methods for data analysis are those mentioned in Numachi et al. (1983).

\section{Results}

Genetic variability and differentiation

No genetic variation was found among 24 loci examined in five out of 12 alcid species.

Table 1. Combinations of tissues and buffer systems for detection of the enzymes

\begin{tabular}{llll}
\hline \multicolumn{1}{c}{ Protein } & Abbr. & \multicolumn{1}{c}{ Tissues } & \multicolumn{1}{c}{ Buffers* } \\
\hline Alcohol dehydrogenase & ADH & Liver & Tris-Citrate \\
Creatine kinase & CK & Muscle & Tris-HCl \\
Diaphorase & DIA & Liver & Tris-HCl \\
Esterase & EST & Liver & Poulik \\
Glutamate dehydrogenase & GDH & Muscle & Tris-HCl \\
$\alpha$-Glycerophosphate dehydrogenase & $\alpha$ GPDH & Muscle & Amine-Citrate \\
Isocitrate dehydrogenase & IDH & Liver & Amine-Citrate \\
Lactate dehydrogenase & LDH & Liver & Amine-Citrate \\
Malate dehydrogenase & MDH & Liver & Amine-Citrate \\
Peptidase & PEP & Muscle & Tris-HCl \\
6-Phosphate dehydrogenase & $6 P G D$ & Liver & Amine-Citrate \\
Phosphoglucomutase & PGM & Liver & Amine-Citrate \\
General protein & PT & Muscle, Liver & Tris-HCl, Poulik \\
Sorbitol dehydrogenase & SDH & Liver & Tris-Citrate \\
Superoxide dismutase & SOD & Liver & Amine-Citrate \\
Xylulose reductase & XR & Liver & Amine-Citrate \\
\hline
\end{tabular}

* Tris-HCl, Poulik: Selander et al. (1971), Amine-Citrate: Kuroda et al. (1982). Tris-Citrate: Numachi et al. (1983) 
Table 2. Proportion of polymorphic loci and average heterozygosity (Observed and Estimated) for each species studied

\begin{tabular}{|c|c|c|c|c|c|}
\hline & \multirow{2}{*}{ Species } & \multirow{2}{*}{$\underset{\text { size }}{\text { Sample }}$} & \multirow{2}{*}{$\begin{array}{c}\text { Proportion of } \\
\text { polymorphic } \\
\text { loci }\end{array}$} & \multicolumn{2}{|c|}{ Average heterozygosity } \\
\hline & & & & Observed & Estimated \\
\hline 1) & Uria lomvia & 4 & 0.125 & 0.031 & 0.043 \\
\hline 2) & Uria aalge & 1 & 0.083 & 0.083 & 0.042 \\
\hline 3) & Cepphus carbo & 5 & 0.083 & 0.025 & 0.021 \\
\hline 4) & Brachyramphus marmoratus & 5 & 0.083 & 0.025 & 0.028 \\
\hline 5) & Synthliboramphus antiquus & 11 & 0.083 & 0.027 & 0.026 \\
\hline 6) & Ptychoramphus aleuticus & 1 & 0 & 0 & 0 \\
\hline 7) & Cyclorrhynchus psittacula & 2 & 0.042 & 0.021 & 0.016 \\
\hline 8) & Aethia cristatella & 10 & 0.042 & 0.017 & 0.029 \\
\hline 9) & Aethia pusilla & 2 & 0 & 0 & 0 \\
\hline 10) & Cerorhinca monocerata & 8 & 0 & 0 & 0 \\
\hline 11) & Fratercula corniculata & 5 & 0 & 0 & 0 \\
\hline \multirow[t]{2}{*}{ 12) } & Lunda cirrhata & 7 & 0 & 0 & 0 \\
\hline & Mean & & 0.045 & 0.019 & 0.017 \\
\hline
\end{tabular}

The sample sizes and genetic variability of all 12 species are shown in Table 2 . The average proportion of polymorphic loci was 0.045 : the highest value was 0.125 , for Uria lomvia. The average heterozygosities also showed similarly low observed $(0.019)$ and estimated (0.017) values. The sample sizes examined were relatively small, ranging from one (Uria aalge and Ptychoramphus aleuticus) to eleven(Synthliboramphus antiquus), but there were no correlations between genetic variability and sample size. Of the 12 alcid species examined, six (U. lomvia, U. aalge, C. carbo, S. antiquus, C. psittacula and A. cristatella) showed intraspecific variation at the EST-2 locus, four ( $U$. lomvia, $U$. aalge, B. marmoratus and $S$. antiquus) at 6PGD, two (U. lomvia and B. marmoratus) at $\alpha$-GPD and only one $(C$. carbo) at PGM-1. Intrageneric variation was found at seven loci (ADH, EST-1, EST-2, and $\alpha$-GPD for Uria and ADH, PGM-2, PT-3 and SOD for Aethia) of the 24 loci.

All taxa were monomorphic for the same allele at eight loci (CK-1, DIA, GDH, IDH-2, MDH-1, PEP, PT-1 and PT-2). The other 16 loci showed interspecific genetic variation. The following three patterns of variation were recognized: 1) many different alleles (EST-2, $\alpha$-GPD, 6PGD, PGM-2 and SOD), 2) alleles forming two or three main groups (CK-2, EST-1, LDH, MDH-2, PT-3, PT-4 and SDH), 3) a few common alleles shared by most species, but unique alleles for some species (ADH, IDH-1, PGM-1 and XR). $\quad C$. monocerata, $F$. corniculata and $L$. cirrhata had the same alleles at $\alpha$-GPD and SOD, although these two loci were highly polymorphic relative to the other loci examined. The twelve species of the Alcidae were divided into two groups based upon CK-2, EST-1, LDH, MDH-1 and SDH, with a few exceptions. One group was comprised of guillemots and murrelets, and the other consisted of an auk, auklets and puffins. This grouping had also been demonstrated in mitochondrial MDH (MDH-2) by Kakizawa et al. (1982). $U$. aalge, B. marmoratus and A. cristalella had species-specific alleles at the ADH locus. $S$. antiquus had species-restricted alleles at $\alpha$-GPD, IDH-1 and XR. At the XR locus, $C$. carbo also had a species-specific allele.

Interspecific genetic distance and identity were calculated from Table 3 using Nei's 


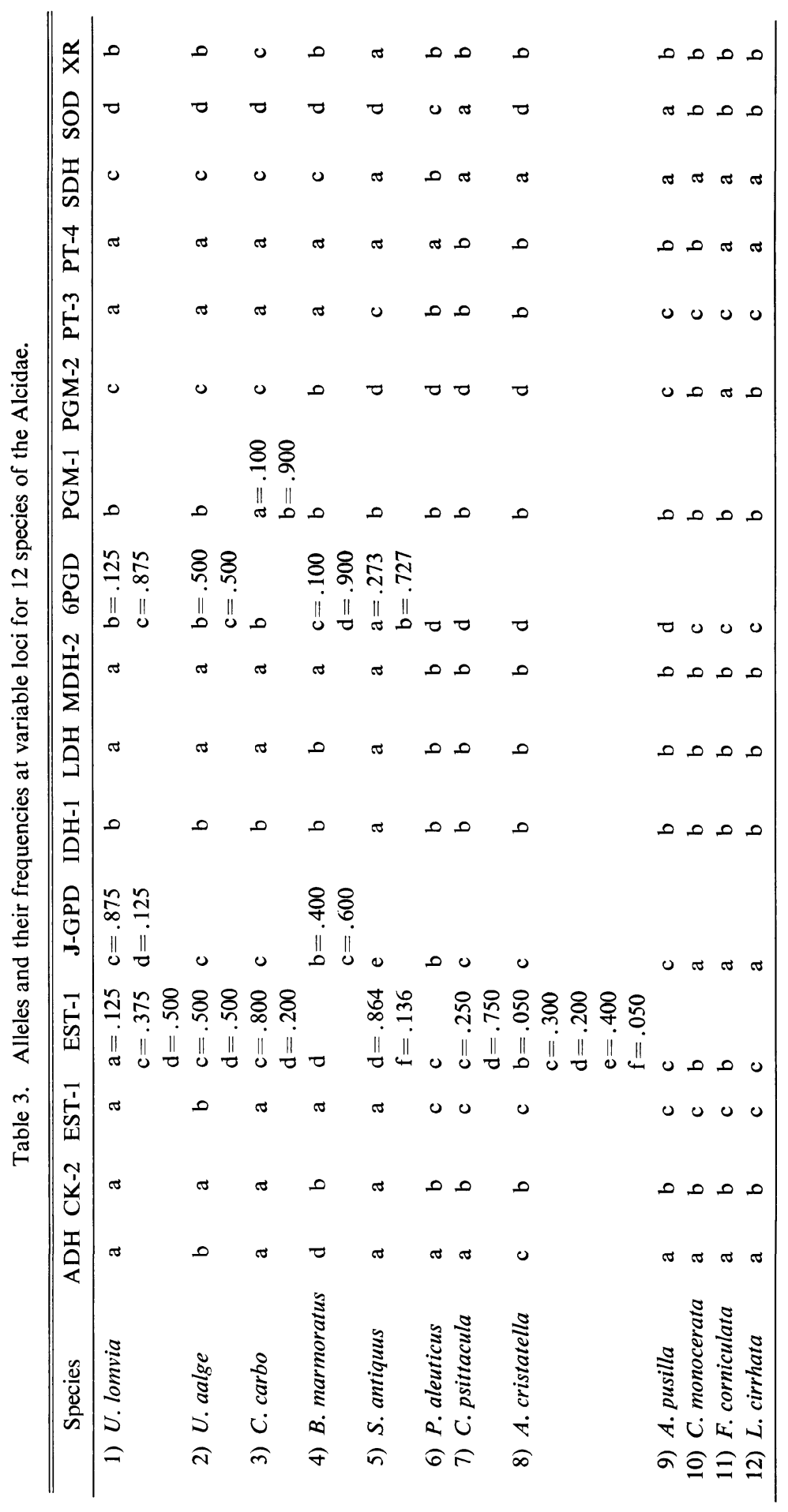


Table 4. Matrix of genetic distance (below diagonal) and genetic identity (above diagonal) for 12 species of Alcidae, based on allele frequencies at 24 loci and calculated by Nei's (1972) formula

\begin{tabular}{|c|c|c|c|c|c|c|c|c|c|c|c|c|}
\hline & (1) & (2) & (3) & (4) & $(5)$ & (6) & (7) & (8) & (9) & (10) & (11) & (12) \\
\hline (1) Uria lomvia & - & .906 & .917 & .782 & .713 & .570 & .573 & .566 & .607 & 7.548 & .591 & .607 \\
\hline (2) Uria aalge & .099 & - & .856 & .740 & .638 & .532 & .536 & .572 & .575 & .489 & .532 & .553 \\
\hline (3) Cepphus carbo & .087 & .156 & - & .713 & .717 & .535 & .520 & .521 & .577 & .459 & .501 & .535 \\
\hline (4) Brachyramphus marmoratus & .246 & .301 & .338 & - & .594 & .646 & .649 & .673 & .613 & .596 & .596 & .638 \\
\hline (5) Synthliboramphus antiquus & .338 & .449 & .333 & .521 & - & .507 & .538 & .522 & .507 & .507 & .549 & .549 \\
\hline (6) Ptychoramphus aleuticus & .563 & .631 & .626 & .436 & .680 & - & .808 & .774 & .750 & .667 & .708 & .750 \\
\hline (7) Cyclorrhynchus psittacula & .557 & .623 & .654 & .432 & .619 & .213 & - & .905 & .892 & 2.756 & .714 & 4.724 \\
\hline (8) Aethia cristatella & .569 & .558 & .653 & .396 & .650 & .256 & .100 & - & .816 & 6.721 & 1.679 & .689 \\
\hline (9) Aethia pusilla & .499 & .554 & .550 & .490 & .680 & .288 & .114 & .203 & - & .792 & 2.750 & .792 \\
\hline (10) Cerorhinca monocerata & .601 & .714 & .779 & .518 & .680 & .405 & .280 & .327 & .234 & - & .917 & 7.917 \\
\hline (11) Fratercula corniculata & .526 & .631 & .691 & .518 & .600 & .345 & .337 & .387 & .288 & .087 & 7 - & .917 \\
\hline (12) Lunda cirrhata & .499 & .592 & .626 & .449 & .600 & .288 & .322 & .372 & .237 & 7.087 & 7.087 & - \\
\hline
\end{tabular}

formula (1972). The matrix of genetic differences and identities between alcid species is shown in Table 4. The genetic distances between two congeneric species pairs were 0.099 (Uria lomvia and $U$. aalge) and 0.203 (Aethia cristatella and A. pusilla): the average was 0.151 . This mean value is higher than the avian mean genetic distance between congeneric species (0.044, Barrowclough 1980). Unexpectedly, the intergenetic distances between the species pairs Uria lomvia and Cepphus carbo $(\mathrm{D}=0.087)$; Cyclorrhynchus psittacula and Aethia cristatella (0.100); and C. psittacula and A. pusilla (0.114), had values

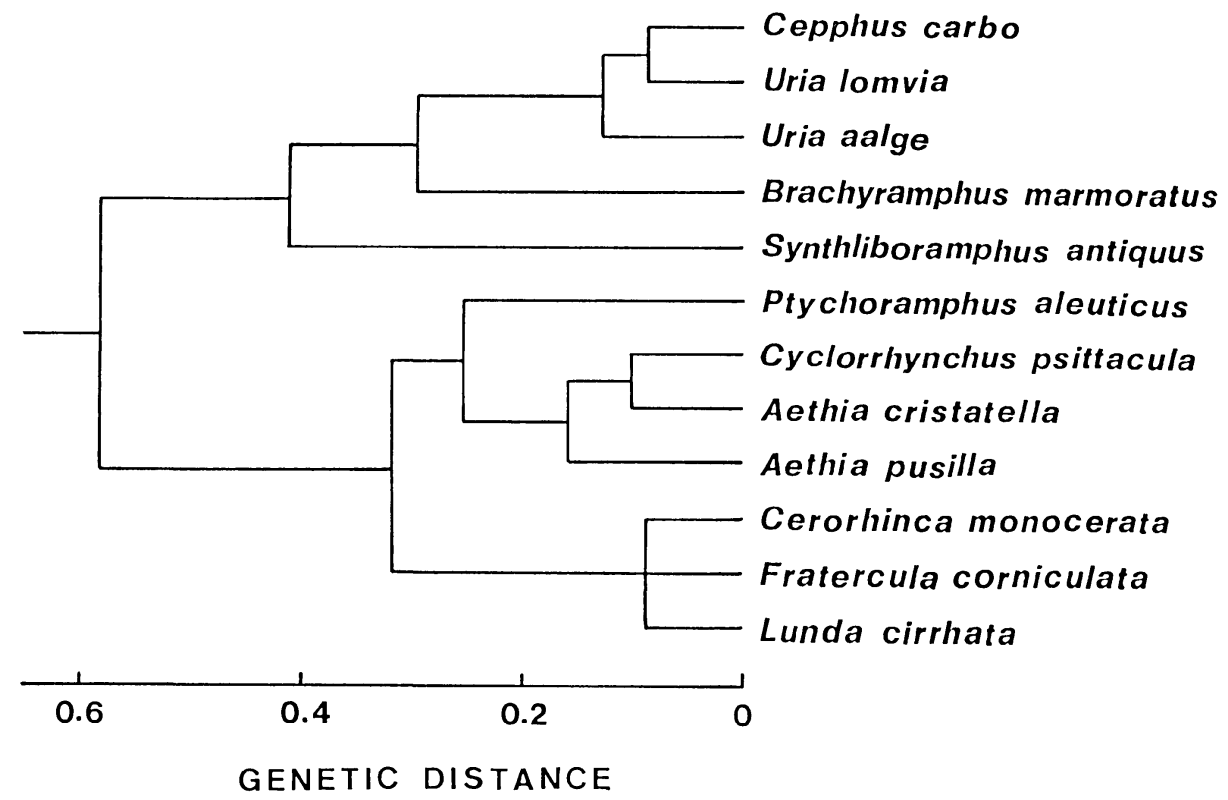

Fig. 1. Dendrogram of 12 species of the Alcidae based on Nei's genetic distances at 24 loci derived by the UPGMA method. 
even lower than those of intrageneric species pairs. Genetic distances among the three puffins (Cerorhinca monocerata, Fraterucula corniculata and Lunda cirrhata) were as low as 0.087 , in spite of morphological differences. The mean genetic distance of the Alcidae was 0.442 at the genus level, higher than the avian mean (0.214, Barrowclough 1980).

\section{Phylogenetic relationships of the Alcidae}

A phenogram of 12 species of the Alcidae was constructed, using genetic distances and the UPGMA method of Sneath \& Sokal (1973). The phenogram (Fig. 1) shows that these 12 species are split into two distinct groups. One group is comprised of the guillemots and murrelets and the other includes an auk, auklets and puffins. Among guillemots, Cepphus carbo and Uria lomvia have a genetic distance smaller than that between $U$. lomvia and U. aalge. Similarly, Cyclorrhynchus and Aethia psittacula are closer to each other than the latter is to Aethia pusilla. The three puffins (Cerorhinca, Fratercula and Lunda), are separated by a genetic distance of 0.087 . The positions of Brachyramphus, Synthliboramphus and Ptychoramphus are somewhat further removed from other genera as shown in Fig. 1. B. marmoratus is split from the Uria-Cepphus cluster at a distance of 0.295. S. antiquus is separated from the above cluster of Uria, Cepphus and Brachyramphus at 0.411. P. aleuticus is segregated from the Cryclorrhynchus-Aethia cluster at a distance of 0.252 .

\section{Discussion}

\section{Genetic variation and differentiation}

The genetic variability of the Alcidae was rather lower than that of birds in general. The proportion of polymorphic loci was 0.045 , and the mean observed and expected heterozygosities were 0.019 and 0.017 , respectively. The avian mean heterozygosity of 0.053 (Barrowclough 1983) is about 2.5 times larger than that of the Alcidae. No significant correlation was observed between sample size and heterozygosity among the 12 alcid species we have studied, which constitute about half of the Alcidae of the world. Therefore, the low level of genetic variability among the Alcidae is probably not due to small sample size, although the possiblity cannot be ruled out.

The Alcidae is a small family consisting of 23 species, split into 13 genera, with an average of 1.8 species per genus. This value is remarkably small:the avian mean species number per genus is 4.4 (Bock \& Farrand 1980). Genetic distances of the Alcidae were 0.151 at the species level and 0.442 at the genus level. These values are rather larger than the respective avian mean distances. These results support the bi-group classification of the Alcidae. At the same time, they indicate the ancient origin of species divergence in this family.

\section{Phylogenetic relationships of the Alcidae}

Although not all alcid genera were treated, two main groups were recognized in this study. This division of the Alcidae has been proposed by Kakizawa et al. (1982) based on an electrophoretic study of mitochondrial MDH (MDH-2 in this study), and is con- 
firmed by the present work on 24 protein loci. In addition to the MDH-2 locus, EST-1, CK-2 and LDH were the key enzyme loci responsible for this two-group division. This bi-group classification originated from Ogilvie-Grant (1898), whose basic division was between Alcinae and Fraterculinae. In the Alcinae, the lores are covered with feathers from the edges of the eyes to the external nostril, which is naked or covered with feathers. On the other hand, Fraterculinae have lore feathers which cover from the edges of the eyes to the base of the bill, but which do not reach the external nostril, which is covered with keratinized scales. The two subfamilies proposed by Ogilvie-Grant have not been used until now. However, bi-group classification based upon protein variations in the Alcidae agrees completely with that of Ogilvie-Grant. In addition, Alcinae and Fraterculinae are separated by a genetic distance of 0.582 , which corresponds to the genetic distance (0.592) between families of the Emberizidae and the Fringilidae (Avise et al. 1980). We conclude that the use of Alcinae and Franterculinae as subfamilies of the Alcidae is worthwhile.

Three groupings of genetically related species of the Alcidae emerged from this study. The first group consists of Uria and Cepphus, which have a similar genetic constitution. Among the three species of Uria and Cepphus, Uria aalge had two speciesspecific alleles at ADH and EST-1, and Cepphus carbo had one species-specific allele at XR. Uria lomvia had two (EST-2 and $\alpha$-GPD), and Cepphus carbo had one (PGM-1) species-specific allele at low frequency. There were no other unique alleles among the three species at the 24 loci studied. Uria and Cepphus had been united (e.g. OgilvieGrant 1898, Hand-List of Japanese Birds 1932, 1942), until the anatomical divergence of Cepphus was reported (Storer 1946, Kuroda 1954). We suggest, based on the present genetic study, that Cepphus should be included in Uria because of the small genetic divergence between the two species.

Uria lomvia and $U$. aalge form a species pair of a similar eco-morphological type with slight differences in structural proportions and tongue shape. $U$. lomvia has a similar tongue shape to that of Cepphus and the puffins. One the other hand, U. aalge has a corneous and slender tongue such as Brachyramphus and Synthliboramphus have, reflecting its food preference (Kuroda 1954, Spring 1971). Species of Uria are offshore deep-sea feeders, while Cepphus is a coastal and bottom feeder with a large gizzard and a long caeca, which are unique among alcid species (Kuroda 1.c.). Osteological wingsternum and leg-pelvis proportions of Cepphus are different from those of Uria, and similar to those of Fraterculinae (Storer 1946, Kuroda 1954). These eco-morphological deviations of Cepphus from Uria seem to be relatively recent events since their genetic relationship was proved to be very close in the present study. On the other hand, Strauch (1985) deduces an entirely different phylogenetic position for Cepphus. He forms the tribe Cepphini, including Synthliboramphus and Endomychura. However, the only key factor uniting them is a clutch size of two eggs, all other taxa having a clutch size of one egg. Strauch himself described the need to obtain biochemical evidence which would suggest genetic relationships of Cepphus to other alcid species.

The second group of closely related species is that including Cyclorrhynchus and Aethia, which showed a pattern simiar to that of Uria and Cepphus. The genetic dis- 
tance between Cyclorrhynchus psittacula and Aethia cristatella was smaller than that between A. cristatella and A. pusilla. In Cyclorrhynchus and Aethia, only Aethia pusilla had species-specific alleles at ADH and EST-2 among 12 species examined. On the other hand, SOD ${ }^{\mathrm{a}}$ was an allele restricted to Cyclorrhynchus and Aethia. There was no allele which distinguished Cyclorrhynchus from Aethia. In morphological studies, the separation of Cyclorrhynchus as a single genus and species from Aethia has been proposed by Kuzlova (1957) based solely on its bill character. Bédard (1969) found a resemblance between the tongues of Cyclorrhynchus and Aethia, although the tongue of the former was narrow compared with that of the plankton-eating Aethia. Kuroda $(1954,1955)$ proposed, based on his osteological study that Cyclorrhynchus should be annexed to Aethia, because he saw no important difference between the two genera. Strauch (1985) also unites Cyclorrhynchus and Aethia in his compatibility analysis of 33 characters in these species.

The third group of closely related species contains the three puffins. Cerorhinca, Fratercula and Lunda are currently treated as generically distinct forms. In this study, however, each puffin had only one allele which was not shared by the other two species. Interestingly, $\alpha-\mathrm{GPD}^{\mathrm{a}}$ and $\mathrm{SOD}^{\mathrm{b}}$ were found only in these three of the 12 alcid species. The genetic distances between these puffins were small $(\mathrm{D}=0.087)$, even lower than the mean genetic distance $(0.151)$ at the species level of the Alcidae. Although each puffin is morphologically distinct, one morphological characteristic common to these three puffins is the dropping of bill appendages after the breeding season. Cerorhinca monocerata has a deciduous elevated horn at the base of the culmen and Fratercula corniculata has eyelids with deciduous horny appendages during the breeding season. Similarly, $F$. corniculata and Lunda cirrhata have a deciduous shield covering the base of the bill. These deciduous phenomen are, however, known in a few other alcids ( $A$. cristatella, Cyclorrhynchus and Alca). In addition, Kuroda (1954, 1955) suggested ostelogically close relatedness among the three puffins. It is likely that Cerorhinca and Lunda are included in Fratercula.

Based on the above genetic data, we divide the 12 alcid species into two subfamilies, Alcinae and Fraterculinae, each of which contains three groups of related species. Alcinae consists of Uria (including Cepphus), Brachyramphus and Synthliboramphus. Fraterculinae consists of Ptychoramphus, Aethia (including Cyclorrhynchus) and Fratercula (including Cerorhinca and Lunda). The above six groups seem to have speciated in relatively ancient periods but species within each group are less diverged genetically in spite of their eco-morphological divergence. Although further study is needed, these recults basically support the current morphological and ecological classification of the Alcidae.

\section{Acknowledgements}

We wish to express our hearty thanks to Dr. H. Ogi and Mr. M. Sekine for providing materials. We also thank Ms. H. Suwa for her technical assistance and Dr. B. W. Lange for reading the manuscript. This work was supported by a grant from the Mitsubishi Foundation. 


\section{References}

Avise, J. C., Patton, J. C. \& Aquadro, C. F. 1980. Evolutionary genetics of birds. II. Conservative protein evolution in North American sparrows and relatives. Syst. Zool. 29: 323-334.

Avise, J. C., Aquadro, C. F. \& Patton, J. C. 1982. Evolutionary genetics of birds. V. Genetic distances within Mimidae (Mimic Thrushes) and Vireonidae (Vireos). Biochem. Genet. 20: 95-104.

Barrowclough, G. H. 1980. Genetic and phenotipic differentiation in a wood warbler (Genus Dendroica) hybrid zone. Auk 97: 655-668.

Barrowclough, G. H. 1983. Biochemical studies of microevolutionary processes. pp. 223-261. In Perspective in Ornithology (A. H. Brush \& G. A. Clark, Jr. Eds.) London, Cambridge University Press.

Bédard, J. 1969. Adaptive radiation in Alcidae. Ibis 111: 189-198.

Bell, L. J., Moyer, J. T. \& Numachi, K. 1982. Morphological and genetic variation in Japanese populations of the Anemonefish Amphiprion clarkii. Marine Biology 72: 99-108.

Bock, W. J. \& Farrand, J. Jr. 1980. The number of species and genera of recent birds: A contribution to comparative systematics. Amer. Mus. Novitates No. 2703: 1-29.

Kakizawa, R., Kuroda, N. \& Utida, S. 1982. Evolution of mitochondrial malate dehydrogenase in birds (II). J. Yamashina Inst. Ornith. 14: 131-136.

Kuroda, N. 1954. On some osteological and anatomical charatcters of Japanese Alcidae (Aves). Jpn. J. Zool. 11: 311-327.

Kuroda, N. 1955. Additional notes on the osteology of Alcidae (Aves). Annot. Zool. Japon. 28: 110113.

Kozlova, E. V. 1957. Charadriiformes, suborder Alcae, In Fauna of USSR Birds. Moskva and Leningrad, The Academy of Science of the USSR.

Morony, J. J., Bock, W. J. \& Farrand, J. Jr. 1975. Reference List of the Birds of the World. New York, Amer. Mus. Nat. Hist.

Nei, M. 1972. Genetic distance between populations. Amer. Natur. 106: 283-292.

Numachi, K., Watada, M., Kakizawa, R., Kuroda, N. \& Utida, S. 1983. Evolutionary genetics of the Anatidae. Tori 32: 63-74.

Ogilvie-Grant, W. R. 1898. Order Alcae. In Cat. Birds Birds Brit. Mus. 26: 559-622.

Ornithological Society of Japan. 1932. Check-list of Japanese Birds. Tokyo.

Ornithological Society of Japan. 1942. Check-list of Japanese Birds. Tokyo.

Selander, R. K., Smith, M. H., Yang, S. Y., Johnson, W. E. \& Gentry, J. B. 1971. Biochemical polymorphism and systematics in the genus Peromyscus. I. Variation in the old-field mouse (Peromyscus polyonotus). Studies in Genetics VI. Univ. Texas Publ. 7103: 49-90.

Shaw, C. R. \& Prasad, R. 1970. Starch gel electrophoresis of enzymes: A compilation of recipes. Biochem. Genet. 4: 297-320.

Sibley, C. G. \& Ahlquist, J. E. 1972. A comparative study of the egg white proteins of non-passerine birds. Bull. Peabody Mus. Hist. 39: 1-276.

Sneath, P. H. \& Sokal, R. R. 1973. Numerical Taxonomy. San Francisco, W. H. Freeman and Co. Spring, L. 1971. A comparison of functional and morphological adaptations in the Common Murre (Uria aalge) and Thick-billed Murre (Uria lomvia). Condor 73: 1-27.

Storer (1946). Structural modification in the hind limb in the Alcidae. Ibis 88: 433-456.

Strauch, J. G. Jr. 1985. The phylogeny of the Alcidae. Auk 102: 502-539.

\section{ウミスズメ科鳥類の遺伝的分化と類縁関係}

ウミスズメ科 10 属 12 種のアイソザイム遺伝子座について電気泳動による分析を行ない, 遺伝的変異や 遺伝的分化の程度を調査し，さらに遺伝的距離に基づく系統樹を作成した。ウミスズメ科の遺伝的変異は 
鳥類の平均と比較するとやや小さく，逆に遺伝的分化の程度はやや高かった。今回調査したウミスズメ科 の類縁関係は一般的には従来の分類と一致しており, ウミガラス属, ケイマフリ属, ウミスズメ属とコウミ スズメ属, ウトウ属, エトピリカ属の 2 つの大きなグループに分割された。しかしながらケイマフリが八 シブトウミガラスと近縁になり, ウミオウムはコウミスズメ属に合一寸ることなどが問題点として残り,こ れらについてはその原因について論議した。

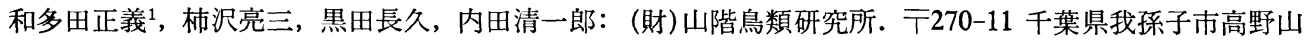

1 現在：アメリカ合衆国国立環境衛生科学研究所．細胞及び遺伝毒性部門 